\title{
Civil Registration: Is It a Right for Vulnerable Groups?
}

\author{
Hariyadi Sabar ${ }^{\bullet}$, Cipta Althaf Ronaza ${ }^{2}$ and Myranda Zahrah Putri ${ }^{3}$
}

Corresponding author.・Email: hariyadi@bappenas.go.id

Submitted: 2021-11-28 | Accepted: 2021-12-13| Published: December $31^{\text {st }} 2021$

\begin{abstract}
A legal identity document is the right of every citizen because it is a prerequisite in accessing public services. This study aims to assess the implementation of Presidential Regulation Number 62 of 2019 on the National Strategy of Strengthening Civil Registration and Vital Statistics (Stranas Percepatan AKPSH), which focuses on regulatory synchronization and services at a local level. A qualitative analysis approach was used, consisting of a literature study and in-depth interview methods. The research sample includes ministries/agencies at the central level, also several local governments, i.e., Palu City, Bantul Regency, Muaro Jambi Regency, East Sumba Regency, DKI Jakarta Province, and Surabaya City. The study shows that the central government has made policies to facilitate vulnerable groups in CRVS access. Local governments have policies that make it easier for vulnerable groups to get CRVS access; innovate administrative services; carry out socialization, advocacy, and education efforts involving third parties; and increase cooperation between regional government organizations (OPD) in implementing integrated civil registration services. However, there are still vulnerable groups that are not accommodated. Implementation at the regional level still has infrastructure readiness, human resources, and required special data collection team availability. Therefore, the determination of the vulnerability category becomes essential. This study recommends that it is necessary to create an additional classification of vulnerable groups in CRVS. In addition, it is essential to strengthening outreach to vulnerable groups in CRVS, especially at the regional level.
\end{abstract}

Keywords: legal identity document; civil registration; vulnerable groups; outreachs; public services.

\footnotetext{
${ }^{1}$ Associate Expert Planner, Directorate of Population and Social Protection Ministry of PPN/BAPPENAS, Jl. HR Rasuna Said, Kuningan, South Jakarta. E-mail: hariyadi@bappenas.go.id.

${ }^{2}$ Planning Analyst, Directorate of Population and Social Protection Ministry of PPN/BAPPENAS, Jl. HR Rasuna Said, Kuningan, South Jakarta. E-mail: cipta.althaf@support.bappenas.go.id

${ }^{3}$ Planning Analyst, Directorate of Population and Social Protection Ministry of PPN/BAPPENAS, J1. HR Rasuna Said, Kuningan, South Jakarta. E-mail: myranda.putri@support.bappenas.go.id
} 


\section{Introduction}

Legal identity documents are the rights of every resident that the state must provide. Ownership of legal identity documents is significant because it is a prerequisite for accessing public services. The coverage of legal identity documents ownership in Indonesia has exceeded the national target. Coverage of birth certificates in 2019 was recorded at $90.53 \%$ (SIAK 2019), which means it is above the target of 90\% (RKP 2019). Likewise, the scope of ownership of a single identity number (NIK) has reached $98.78 \%$, which is greater than the target of $90 \%$ (RKP 2019). However, these achievements at the regional level have not shown satisfactory results, such as national achievements. Several provinces, such as Papua, Maluku, and East Nusa Tenggara, have birth certificates and NIK coverage below 90\%.

To encourage coverage of national civil registration, the Government of Indonesia has issued Presidential Regulation Number 62 of 2019 on the National Strategy of Strengthening Civil Registration and Vital Statistics (Stranas Percepatan AKPSH), especially for vulnerable populations in CVRS. The National Strategy has 3 (three) objectives, i.e., 1) Accelerating civil registration and developing universal and inclusive vital statistics; 2) Provide complete and up-to-date residence documents for all residents; 3) Provide accurate, complete, and timely vital statistics. Technically, this policy is supported by the Minister of Home Affairs Regulation Number 96 of 2019 (Permendagri 96/2019) on the Guidelines for Data Collections and Issuance of Legal Identity Documents for Vulnerable populations in CRVS.

It regulates general provisions, organizers, procedures, form specifications, and funding to issue vulnerable populations' legal identity documents. Vulnerable populations in CRVS are defined as people who experience obstacles in obtaining legal identity documents due to specific conditions, which include: 1) Natural Disaster Victims; 2) Social Disaster Victims; 3) Neglected Persons; 4) Remote Communities; 5) Residents on Forest Areas, State Lands, and Disputed Land. This group has difficulty accessing essential services such as education, health, social protection programs because they cannot verify their identity as citizens.

Therefore, it is necessary to assess the implementation of Presidential Regulation Number 62 of 2019. The study focused on Strategy Number Three of the Acceleration of Legal Identity Document Ownership for CRVS Vulnerable Populations and Special Groups. This study is expected to collect information on the implementation of regulations, achievements, innovations, and challenges practical as recommendations in planning a more inclusive civil registration program for the vulnerable population.

Regarding access to vulnerable groups in population administration, the study conducted by Bennouna et al. (2016) developed a framework model that examines barriers to access to civil registration services in Indonesia, called The Three-Delays Model. There are three stages that a person goes through to access residence documents, as follows: 
Factors Affecting Utilization and Outcome
Phase of Delay

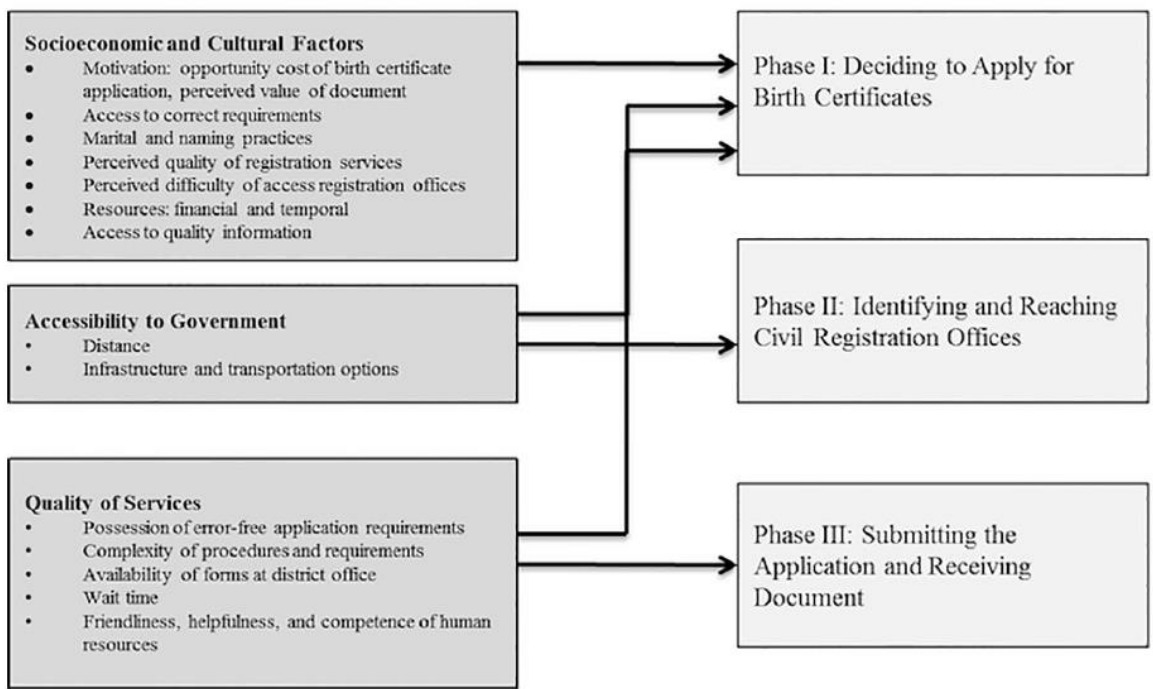

Fig 1. Adaptation of the Three Delays Model for Civil Registration.

Figure 1. Adaptation of the Three-Delays Model for Civil Registration. (Bennouna et al., 2016)

The first stage in the scheme is determining to submit a birth registration (as an example, as part of a residence document). Then, the second stage is the identification and outreach process for civil registration service provider offices. The last is the collection of application files and the issuance of residence documents. In these three phases, there can be obstacles caused by:

a. Socio-Economic and Cultural Factors.

Includes motivation, understanding of the urgency of document ownership, access to document requirements, marriage practices, quality of registration services obtained, difficulties in accessing places of service provision, financial and time resources, and access to quality information.

b. Accessibility to Government.

Includes distance, infrastructure, and transportation options.

c. Service quality.

Includes the need for service provider applications free from errors, the complexity of procedures and requirements, availability of forms at service provider offices at the district/city level, waiting times, readiness, and competence of service personnel.

In the first phase, there may be obstacles caused by socio-economic and cultural factors, access to government, and service quality. In the second phase, the obstacle comes from accessibility to the Government. Meanwhile, in the third phase, obstacles can come from service quality. (Bennouna et al., 2016)

Effective policies can play a significant role in increasing birth and death registration rates globally. The central government needs to understand the barriers faced by population administration vulnerable groups to plan and develop the most effective and efficient policy mechanisms for each category of these groups. Further studies are needed to examine a systematic intervention policy approach in design, planning, implementation, and evaluation to increase access, resource requirements, and policy acceptability to strengthen the population registration system and civil registration. (Suthar et al., 2019) 


\section{Methodology}

This study uses descriptive qualitative analysis to analyze and describe phenomena or research objects based on social activities, attitudes, opinions/ideas, and perceptions of people both individually and in groups (Sugiyono, 2018). In this qualitative study, the data collection methodology will be carried out through 1) Coordination meetings to review the implementation of regulations and administration of population document services for vulnerable populations in CRVS; 2) In-depth interviews with selected respondents; and 3) Questionnaires with stakeholders at the central and regional levels to explore strategies, innovations, and challenges for administrative services for vulnerable populations. Furthermore, data from interviews, notes, and field documentation will be analyzed interactively. The data will be arranged systematically and categorized according to the indicators to make easily understood conclusions (Sugiyono, 2018). Qualitative analysis will focus on a detailed description of the phenomenon of providing legal identity documents for vulnerable populations. This is done based on the indicators set in each selected study area and the summary of the key informant interviews.

Sugiyono (2018) explains the stages of data analysis consisting of:

1) Data Reduction.

Data are summarized and grouped by indicators. Unneeded data will be removed so that the reduced data will provide a clear and detailed picture. These results will be verified, and conclusions will be drawn.

2) Data Presentation.

This process includes compiling relevant data and describing the information obtained to map the meaning of the research.

3) Verification/Conclusion.

Verification of data and concluding the form of a summary of the theory and description of the object under study

The activity steps of the study include coordinating meetings with partner Ministries/Institutions (Directorate General of Population and Civil Registration, Ministry of Home Affairs, Indonesian-Australian Government Partnership KOMPAK, Center for Advocacy and Child Protection Studies University of Indonesia/PUSKAPA UI); coordination meetings related to monitoring instruments; regulatory analysis based on monitoring indicators in the AKPSH National Strategy; online interviews with the Population and Civil Registration Office; and preparation of reports.

The study was carried out for 12 (twelve) months, consisting of field visits and interviews at the Central and Regional levels. Monitoring at the national level is focused on the regulatory synchronization aspect. Meanwhile, it will focus on the service aspect for adminduk vulnerable populations at the regional level. Monitoring at the regional level uses a sample of vulnerable population groups according to the classification according to Permendagri 96/2019. The selected areas consist of Palu City, Bantul Regency, Muaro Jambi Regency, East Sumba Regency, DKI Jakarta Province, and Surabaya City. The selection of areas in this study considers aspects of vulnerability based on the situation in each area, which is described in detail in Table 1. 
Table 1. Consideration Factors for Choosing City/District Areas

\begin{tabular}{|c|c|c|}
\hline No. & City/Districts & Regional Selection Considerations \\
\hline 1. & Palu City & $\begin{array}{l}\text { In } 2018 \text {, the } 7.4 \text { SR earthquake in Palu City, followed by a } \\
\text { tsunami, caused damage to buildings and loss of life (an } \\
\text { estimated 66,390 houses were destroyed, and 2,045 people } \\
\text { died). (Widarti Gularsih Sukino et al., 2019) } \\
\text { The city of Palu was chosen to find out how the CRVS } \\
\text { services vulnerable residents due to natural disasters. }\end{array}$ \\
\hline 2. & Bantul District & $\begin{array}{l}\text { Bantul Regency has a relatively large } 508.13 \mathrm{~km} 2 \text { with } 17 \\
\text { sub-districts and } 75 \text { villages. The data shows that there are } \\
232 \text { neglected children and } 145 \text { abandoned parents who are } \\
\text { registered. Bantul Regency was chosen to determine how } \\
\text { CRVS services are provided to neglected people in a } \\
\text { reasonably large area. (Rijanta et al., 2019) }\end{array}$ \\
\hline 3. & $\begin{array}{l}\text { Muaro } \\
\text { District }\end{array}$ & $\begin{array}{l}\text { Suku Anak Dalam, who live nomadically (moving around), } \\
\text { can be categorized as vulnerable populations in CRVS and are } \\
\text { still in Jambi Province. } \\
\text { The choice of Muaro Jambi Regency as the monitoring } \\
\text { location because Muaro Jambi Regency has three sub- } \\
\text { districts (Mestong, North Bahar, and South Bahar) which are } \\
\text { the movement areas of Suku Anak Dalam. This study is } \\
\text { expected to provide lessons about CRVS services for } \\
\text { indigenous communities. }\end{array}$ \\
\hline 4. & $\begin{array}{l}\text { East } \\
\text { District }\end{array}$ & $\begin{array}{l}\text { East Sumba Regency has the third-largest number of } \\
\text { believers with the most famous belief, namely Marapu. } \\
\text { East Sumba Regency is chosen to find out more about CRVS } \\
\text { services for religious groups, especially Marapu. }\end{array}$ \\
\hline 5. & $\begin{array}{l}\text { DKI Jakarta } \\
\text { Province and } \\
\text { Surabaya City }\end{array}$ & $\begin{array}{l}\text { Special Capital Region of Jakarta and the City of Surabaya are } \\
\text { two regions that have become the epicenters of the Covid-19 } \\
\text { virus pandemic in Indonesia. Therefore, adjustments were } \\
\text { made to implementing public services, both online and } \\
\text { physical interaction restrictions. This condition led to the } \\
\text { issuance of a Large-Scale Social Restriction (PSBB) policy. } \\
\text { The Province of DKI Jakarta and the City of Surabaya were } \\
\text { selected to find out more about how civil registration services } \\
\text { for the vulnerable populations in CRVS are administered } \\
\text { during a pandemic situation that reduces physical interaction. }\end{array}$ \\
\hline
\end{tabular}

The indicators used in this study refer to Presidential Regulation Number 62 of 2019, the National Strategy for the Acceleration of Strengthening Civil Registration and Vital Statistics (Stranas AKPSH), and in particular support Strategy Number Three of the Acceleration of Legal Identity Document Ownership for CRVS Vulnerable Populations and Special Groups. Based on Strategy Number Three, table 2 describes policy directions, targets, outputs, and monitoring indicators. 
Table 2. Policy Directions, Goals, Outputs, and Monitoring Indicators based on Strategy 3 of the AKPSH National Strategy

\begin{tabular}{|c|c|c|c|c|c|}
\hline No. & $\begin{array}{c}\text { Policy } \\
\text { Directions. }\end{array}$ & Goals. & Outputs. & & $\begin{array}{l}\text { Monitoring } \\
\text { Indicators. }\end{array}$ \\
\hline \multirow[t]{4}{*}{1.} & \multirow{4}{*}{$\begin{array}{l}\text { Develop } \\
\text { particular } \\
\text { group } \\
\text { classifications } \\
\text { and } \\
\text { characteristics } \\
\text { of } \\
\text { vulnerability } \\
\text { in accessing } \\
\text { CRVS } \\
\text { services. }\end{array}$} & \multirow{4}{*}{$\begin{array}{l}\text { In 2020, the } \\
\text { classification of } \\
\text { vulnerable } \\
\text { populations and } \\
\text { special groups in } \\
\text { CRVS and } \\
\text { vulnerability } \\
\text { characteristics in } \\
\text { accessing CRVS } \\
\text { services will be } \\
\text { developed. }\end{array}$} & $\begin{array}{l}\text { Classification } \\
\text { (location } \\
\text { number) and } \\
\text { populations of } \\
\text { special groups in } \\
\text { CRVS and their } \\
\text { characteristics of } \\
\text { vulnerability. }\end{array}$ & \multirow[t]{2}{*}{ 1) } & \multirow{2}{*}{$\begin{array}{l}\text { Classification } \\
\text { and } \\
\text { Characteristics } \\
\text { of CVRS } \\
\text { Vulnerable } \\
\text { Populations; } \\
\text { Legal Analysis } \\
\text { and Study of } \\
\text { Vulnerability } \\
\text { and Barriers. }\end{array}$} \\
\hline & & & $\begin{array}{l}\text { Analysis and legal } \\
\text { review of } \\
\text { vulnerabilities and } \\
\text { barriers } \\
\text { populations of } \\
\text { special groups in } \\
\text { CRVS services. }\end{array}$ & & \\
\hline & & & $\begin{array}{l}\text { All districts/cities } \\
\text { have a cross-sector } \\
\text { team for CRVS } \\
\text { vulnerable } \\
\text { population data } \\
\text { collection to reach } \\
\text { out to the kelurahan } \\
\text { or village. }\end{array}$ & 2) & $\begin{array}{l}\text { Development of } \\
\text { the Data } \\
\text { Collection } \\
\text { Team for CRVS } \\
\text { Vulnerable } \\
\text { Populations. }\end{array}$ \\
\hline & & & $\begin{array}{lr}\text { Policy for } & \text { CRVS } \\
\text { vulnerable } & \\
\text { populations } & \text { and } \\
\text { special groups to } \\
\text { have access to } \\
\text { CRVS services. }\end{array}$ & 3) & $\begin{array}{l}\text { Government } \\
\text { Policy to } \\
\text { Facilitate } \\
\text { Access } \\
\text { Vulnerable } \\
\text { Populations to } \\
\text { access Legal } \\
\text { Identity } \\
\text { Document. }\end{array}$ \\
\hline 2. & $\begin{array}{l}\text { Policies } \\
\text { formulation } \\
\text { regarding } \\
\text { CRVS } \\
\text { services } \\
\text { technical } \\
\text { guidelines } \\
\text { that } \\
\text { accommodate } \\
\text { special needs } \\
\text { groups. }\end{array}$ & $\begin{array}{l}\text { In 2021, CRVS } \\
\text { Services technical } \\
\text { guidelines for } \\
\text { Vulnerable } \\
\text { Populations and } \\
\text { special groups are } \\
\text { available. }\end{array}$ & $\begin{array}{l}\text { Recommendations } \\
\text { for synchronizing } \\
\text { CRVS laws and } \\
\text { regulations with } \\
\text { policies related to } \\
\text { Vulnerable Groups } \\
\text { in CRVS and } \\
\text { Special Groups. }\end{array}$ & 4) & $\begin{array}{l}\text { Synchronization } \\
\text { of Legislation. }\end{array}$ \\
\hline
\end{tabular}




\begin{tabular}{|c|c|c|c|c|c|}
\hline & & & $\begin{array}{l}\text { Technical } \\
\text { guidelines for } \\
\text { CRVS services for } \\
\text { Vulnerable } \\
\text { Populations and } \\
\text { Special Groups. }\end{array}$ & 5) & $\begin{array}{l}\text { Services } \\
\text { Technical } \\
\text { Guidelines. }\end{array}$ \\
\hline \multirow[t]{4}{*}{3.} & $\begin{array}{l}\text { Services to all } \\
\text { CRVS } \\
\text { Vulnerable } \\
\text { Groups and } \\
\text { Special } \\
\text { Groups in } \\
\text { obtaining } \\
\text { Legal Identity } \\
\text { Documents. }\end{array}$ & $\begin{array}{l}\text { In 2021, CRVS } \\
\text { vulnerable } \\
\text { populations and } \\
\text { special groups are } \\
\text { served to obtain } \\
\text { legal identity } \\
\text { documents. }\end{array}$ & 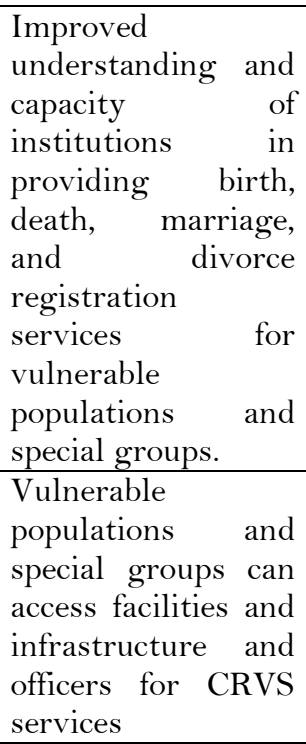 & 6) & $\begin{array}{l}\text { Readiness of } \\
\text { Infrastructure } \\
\text { Facilities and } \\
\text { Service } \\
\text { Officers. }\end{array}$ \\
\hline & & & $\begin{array}{l}\text { We are increasing } \\
\text { access and coverage } \\
\text { of legal identity } \\
\text { ownership for } \\
\text { vulnerable } \\
\text { populations } \\
\text { special groups. }\end{array}$ & 7) & $\begin{array}{l}\text { Service } \\
\text { Innovation to } \\
\text { Reach CRVS } \\
\text { Vulnerable } \\
\text { Populations. }\end{array}$ \\
\hline & & & $\begin{array}{lr}\text { CRVS } & \text { integrated } \\
\text { services } & \text { for } \\
\text { vulnerable } & \text { groups } \\
\text { and special groups. }\end{array}$ & 8) & $\begin{array}{l}\text { Integrated } \\
\text { Services. }\end{array}$ \\
\hline & & & $\begin{array}{l}\text { It is waiving court } \\
\text { fees and legal } \\
\text { assistance policies } \\
\text { for processing } \\
\text { applications of } \\
\text { marriages } \\
\text { ratification (its bat) } \\
\text { or divorces } \\
\text { experienced by } \\
\text { vulnerable }\end{array}$ & & \\
\hline
\end{tabular}




\begin{tabular}{|c|c|c|c|c|}
\hline & & & $\begin{array}{l}\text { populations and } \\
\text { special groups. }\end{array}$ & \\
\hline \multirow[t]{3}{*}{4.} & $\begin{array}{l}\text { Increased } \\
\text { knowledge } \\
\text { and activity of } \\
\text { CRVS } \\
\text { Vulnerable } \\
\text { Population } \\
\text { and special } \\
\text { groups in } \\
\text { recording } \\
\text { population } \\
\text { events and } \\
\text { essential } \\
\text { events } \\
\text { experienced }\end{array}$ & $\begin{array}{l}\text { At the end of } \\
2022, \\
\text { knowledge and } \\
\text { activity } \\
\text { vulnerable } \\
\text { populations and } \\
\text { special groups in } \\
\text { recording vital } \\
\text { events } \\
\text { increase. }\end{array}$ & $\begin{array}{l}\text { The reference } \\
\text { information of } \\
\text { CRVS requirements } \\
\text { and procedures is } \\
\text { accessible } \\
\text { Vulnerable to } \\
\text { populations and } \\
\text { Special Groups. }\end{array}$ & $\begin{array}{l}\text { Reference } \\
\text { Information } \\
\text { about Terms } \\
\text { and Procedures. }\end{array}$ \\
\hline & & & $\begin{array}{l}\text { Vulnerable } \\
\text { populations and } \\
\text { Special Groups } \\
\text { participated actively } \\
\text { in the formulation } \\
\text { of service policies. }\end{array}$ & \multirow{2}{*}{$\begin{array}{l}\text { 10) Socialization, } \\
\text { Advocacy, } \\
\text { Service } \\
\text { Education and } \\
\text { Enthusiasm of } \\
\text { Vulnerable } \\
\text { Populations. }\end{array}$} \\
\hline & & & $\begin{array}{l}\text { Socialization, } \\
\text { Advocacy, and } \\
\text { Education of CRVS } \\
\text { Services. }\end{array}$ & \\
\hline
\end{tabular}

Based on Table 2, 10 (ten) indicators were developed, divided into monitoring at the central and regional levels as shown in Table 3.

Table 3. Monitoring Points

\begin{tabular}{|l|l|l|}
\hline No. & Central Government. & Regional Government. \\
\hline 1. & $\begin{array}{l}\text { Classification and Characteristics of } \\
\text { CVRS Vulnerable Populations; Legal } \\
\text { Analysis and Study of Vulnerability and } \\
\text { Barriers. }\end{array}$ & $\begin{array}{l}\text { Data Collection Team for Vulnerable } \\
\text { Populations CRVS. }\end{array}$ \\
\hline 2. & Synchronization of Legislation. & $\begin{array}{l}\text { Service Innovation to Reach CRVS } \\
\text { Vulnerable Populations. }\end{array}$ \\
\hline 3. & Service Technical Guidelines. & $\begin{array}{l}\text { Readiness of Infrastructure Facilities } \\
\text { and Service Officers }\end{array}$ \\
\hline 4. & $\begin{array}{l}\text { Central Government policies to make } \\
\text { Vulnerable Populations easier to access } \\
\text { Legal Identity Documents. }\end{array}$ & $\begin{array}{l}\text { Local Government policies to make } \\
\text { Vulnerable Populations easier to access } \\
\text { Legal Identity Documents. }\end{array}$ \\
\hline 5. & & $\begin{array}{l}\text { Reference Information about Terms and } \\
\text { Procedures. }\end{array}$ \\
\hline 6. & & $\begin{array}{l}\text { Outreach, Advocacy, and Service } \\
\text { Education }\end{array}$ \\
\hline 7. & & Integrated Service. \\
\hline
\end{tabular}




\section{Results, Analysis, and Discussions}

\subsection{Central Government}

Studies at the Central Government level focus on supporting policies, regulations, and governance on a national scale with the following results:

\subsubsection{Classification and Characteristics of CVRS Vulnerable Populations; Legal Analysis and Study of Vulnerability and Barriers}

The regulations that mention the classification of the administratively vulnerable population are Presidential Regulation Number 62 of 2019 and Ministry of Home Affairs Regulation Number 96 of 2019. The definitions and classifications are described in detail in Table 3.

Table 3. Classification of Population Administration Vulnerable Groups according to Presidential Decree 62/2019 and Minister of Home Affairs 96/2019

\begin{tabular}{|c|c|c|c|}
\hline \multirow[t]{2}{*}{ No. } & $\begin{array}{l}\text { Presidential } \\
\text { Decree } \\
62 / 2019 \\
\end{array}$ & Permendagri 96/2019 & \multirow[t]{2}{*}{ Definition/Characteristics } \\
\hline & \multicolumn{2}{|l|}{ Classification } & \\
\hline 1. & $\begin{array}{l}\text { Natural } \\
\text { Disaster } \\
\text { Victims }\end{array}$ & Natural Disaster Victims & $\begin{array}{l}\text { Indonesian citizens/foreigners } \\
\text { who experience a series of events } \\
\text { caused by nature including } \\
\text { earthquakes, tsunamis, volcanic } \\
\text { eruptions, floods, droughts, } \\
\text { hurricanes, and landslides. }\end{array}$ \\
\hline 2. & $\begin{array}{l}\text { Social Disaster } \\
\text { Victims }\end{array}$ & Social Disaster Victims & $\begin{array}{l}\text { Indonesian citizens/foreigners } \\
\text { experience a series of events } \\
\text { caused by humans, including social } \\
\text { conflicts, groups, communities, } \\
\text { and terrorism. }\end{array}$ \\
\hline 3. & $\begin{array}{l}\text { Neglected } \\
\text { People }\end{array}$ & Neglected People & $\begin{array}{l}\text { Indonesian citizens who for some } \\
\text { reason cannot meet their needs } \\
\text { adequately, whether spiritually, } \\
\text { physically, or socially. }\end{array}$ \\
\hline 4. & $\begin{array}{l}\text { Indigenous } \\
\text { Groups }\end{array}$ & Indigenous Groups & $\begin{array}{l}\text { Socio-cultural groups are local and } \\
\text { dispersed and less involved in } \\
\text { social, economic, and political } \\
\text { networks and services. }\end{array}$ \\
\hline 5. & - & $\begin{array}{l}\text { Residents on Forest Areas, } \\
\text { State Lands, and Disputed } \\
\text { Land }\end{array}$ & $\begin{array}{l}\text { Residents who control and use } \\
\text { state land directly, whether } \\
\text { registered as assets or not. }\end{array}$ \\
\hline
\end{tabular}

According to the regulation, it is estimated that there are five classifications of the population vulnerable to CRVS. To identify the possibility of a classification of the population as vulnerable to CRVS outside the five groups, the Ministry of National Development Planning/Bappenas, in collaboration with KOMPAK and the Center on Child Protection and Wellbeing (Puskapa) of the University of Indonesia, conducted a study entitled CRVS Vulnerability in 2019. The study analyzed the classification and characteristics of the vulnerability of the adminduk vulnerable population, both those that have been and have not been covered by Presidential Decree 62/2019 and Minister of Home Affairs Regulation 96/2019. This study explains what each vulnerable population experiences vulnerabilities as a first step to developing better outreach methods. The study results are described in Table 4 below. 
Table 4. CRVS Vulnerability Result (Bappenas, KOMPAK, and PUSKAPA)

(PUSKAPA), 2020)

\begin{tabular}{|c|c|c|c|}
\hline No. & Vulnerability & Classification & Definition/Characteristics \\
\hline 1. & \multirow{3}{*}{ Access Barriers. } & $\begin{array}{l}\text { Residents with Geographical and } \\
\text { Mobility Constraints to Reach } \\
\text { Services. }\end{array}$ & $\begin{array}{l}\text { Residents in Remote Areas, } \\
\text { Borders, or Archipelago } \\
\text { Areas. }\end{array}$ \\
\hline 2. & & $\begin{array}{l}\text { Residents with Economic } \\
\text { Constraints to Reach Services. }\end{array}$ & Poor and Very Poor People. \\
\hline 3. & & $\begin{array}{lrr}\text { Residents Who Don't } & \text { Have } \\
\text { Sufficient Information } & \text { and } \\
\text { Ability to Reach Services. } & \end{array}$ & $\begin{array}{l}\text { Population without Access } \\
\text { to Information, Low } \\
\text { Education, Illiteracy, } \\
\text { Language Barriers. }\end{array}$ \\
\hline 4. & \multirow{7}{*}{$\begin{array}{l}\text { Unresponsive } \\
\text { Services and } \\
\text { Systems. }\end{array}$} & $\begin{array}{l}\text { Residents with Domicile } \\
\text { Problems. }\end{array}$ & $\begin{array}{l}\text { Homeless, Indigenous } \\
\text { Groups, Frontier } \\
\text { Community Groups, } \\
\text { Migrant Workers, People } \\
\text { Living in Forest Areas, } \\
\text { Government Land. }\end{array}$ \\
\hline 5. & & People with Disabilities. & Anyone with Disabilities. \\
\hline 6. & & $\begin{array}{l}\text { Residents in Institutions or } \\
\text { Outside Traditional Households. }\end{array}$ & $\begin{array}{l}\text { Residents Living in } \\
\text { Orphanages, Prisons, } \\
\text { Islamic Boarding Schools, } \\
\text { or Streets. }\end{array}$ \\
\hline 7. & & $\begin{array}{l}\text { Residents with Special Marital } \\
\text { Status. }\end{array}$ & $\begin{array}{l}\text { Polygamy, Religious or } \\
\text { Customary Marriage Only, } \\
\text { Unregistered Marriage, } \\
\text { Child Marriage, Marriage } \\
\text { with Asylum } \\
\text { Seekers/Foreigners. }\end{array}$ \\
\hline 8. & & $\begin{array}{l}\text { Residents in } \quad \text { Special } \\
\text { Circumstances. }\end{array}$ & $\begin{array}{l}\text { Population Affected by } \\
\text { Natural Disasters, War, } \\
\text { Social Disasters. }\end{array}$ \\
\hline 9. & & $\begin{array}{l}\text { Residents with Citizenship } \\
\text { Problems. }\end{array}$ & $\begin{array}{l}\text { Indonesian citizens who } \\
\text { decide to become foreigners } \\
\text { but are still registered in the } \\
\text { system, Indonesian } \\
\text { citizens/foreigners with } \\
\text { dual citizenship. }\end{array}$ \\
\hline 10. & & $\begin{array}{l}\text { Residents without any Legal } \\
\text { Identity Documents. }\end{array}$ & $\begin{array}{l}\text { Residents Who Have Never } \\
\text { Had a Legal Identity } \\
\text { Document (so it is difficult } \\
\text { to ensure their legality as } \\
\text { residents of certain regions). }\end{array}$ \\
\hline 11. & \multirow[b]{2}{*}{ Social Identity } & $\begin{array}{l}\text { Residents whose identity has not } \\
\text { been or is bettered by the state. }\end{array}$ & $\begin{array}{l}\text { Residents with Minority } \\
\text { Religion, Asylum Seekers. }\end{array}$ \\
\hline 12. & & $\begin{array}{l}\text { Residents Who Get Stigma from } \\
\text { Society. }\end{array}$ & $\begin{array}{l}\text { Persons with Mental } \\
\text { Disorders, Sexual Identity, } \\
\text { Ethnic Minorities, Children } \\
\text { outside Legal Marriage. }\end{array}$ \\
\hline
\end{tabular}

Source: CRVS Vulnerability Study, Puskapa Publication 2020

Based on the study, 12 (twelve) classifications of the vulnerable population are proposed to be accommodated on CRVS system, which includes: 1) Population with 
Geographical and Mobility Constraints to Reach Services; Population with Economic Constraints to Reach Services; 2) Residents Who Do not Have Sufficient Information and Ability to Reach Services; 3) Residents with Domicile Problems; 4) People with Disabilities; 5) Residents residing in institutions or outside traditional households; 6) Residents with Special Marital Status; 7) Residents in Special Circumstances; 8) Residents with Citizenship Problems; 9) Residents without any Legal Identity Documents); 10) Residents whose identity has not been/ignored by the state; 11) People Who Get Stigma from Society. In general, a population can be said to be in a vulnerable condition in CRVS if it has geographical, mobility, and economic constraints in reaching CRVS services (KOMPAK \& PUSKAPA, 2020).

\subsubsection{Synchronization of Laws and Regulations}

The laws and regulations related to vulnerable populations in CRVS are substantially aligned. However, in the AKPSH National Strategy, one of the vulnerable population classifications is special groups. Special groups are population groups that need special attention in the outreach of CRVS services due to certain conditions. According to Presidential Decree 62/2019, special groups consist of 1) Indigenous Peoples; 2) Believers; 3) Nomadic people/whose life is nomadic; 4) Children/Adults living on the street; 5) Children from mixed marriages/asylum seekers/Indonesian Migrant Workers; 6) Spouses from low-income families who are divorced but do not have proof of divorce; 7) Indonesian migrant workers with problems; 8) Other special groups according to the laws and regulations. Whereas in Permendagri 96/2019, there is a particular group classification in Residents on Forest Areas, State Lands, and Disputed Land.

\subsubsection{Service Technical Guidelines}

Technical guidelines in services for vulnerable populations in CRVS are described in detail in Permendagri Number 96 of 2019, which includes: a) Definition and classification of CRVS vulnerable populations; b) Operator of data collection and issuance of legal identity documents for vulnerable populations in CRVS; c) Specific procedures in data collection and issuance of legal identity documents for vulnerable populations in each classification; d) Types, specifications of forms, and certificates for issuing legal identity documents for CRVS vulnerable population; e) Funding for data collection and legal identity documents issuance for vulnerable populations in each classification.

\subsubsection{Central Government policies to make Vulnerable Populations easier to access Legal Identity Documents}

The policies that have been issued, i.e.:

a) Law Number 24 of 2013 amendment to Law Number 23 of 2006 on Population Administration and Presidential Decree No. 40/2019 on implementing changes to Law 24/2013 regarding general administrative services. (Law Number 24 of 2013, 2013)

b) Minister of Home Affairs Regulation 19/2018 concerning the Quality Improvement of Population Administration Services regarding outreaching services for residents who are not accessible, sick, in penitentiary services, and cannot be present at administrative service places. (Regulation of the Minister of Home Affairs Number 19 of 2018 concerning the Quality Improvement of Population Administration Services, 2018)

c) Minister of Home Affairs Regulation 96/2019 concerning Data Collection on Issuance of Legal Identity Documents for Vulnerable Populations regarding outreaching services for CRVS vulnerable populations. 
d) Minister of Home Affairs Regulation 9/2016 concerning the Acceleration of Increasing the Coverage of Birth Certificate Ownership regarding the issuance of SPTJM ${ }^{4}$ (Statement of Absolute Responsibility) for the truth of birth data and the truth as a married couple.

e) Law 16 of 2019 concerning Marriage, Minister of Religion Regulation 19/2018 concerning Marriage Registration, and Minister of Home Affairs Regulation 12/2010 concerning Guidelines for Marriage Registration and Reporting of Deeds Issued by Other Countries regarding special marriage services (Law Number 16 of 2019 concerning Amendments to Law Number 1 of 1974 concerning Marriage., 2019).

f) Minister of Home Affairs Regulation 7/2019 concerning Online Population Administration Services regarding online administrative services.

g) The Constitutional Court's decision 97/2016 regarding the verification of the registration of belief in the Ministry of Education and Culture and emptying the religion column for religions outside the six major religions.

Overall, the study results at the central level illustrate that victims of non-natural disasters have not been categorized as the CRVS vulnerable population in the applicable regulations in Indonesia.

\subsection{Provincial and District Government}

The COVID-19 pandemic, which is designated as a non-natural disaster on a national scale based on Presidential Decree no. 12 of 2020 , caused study activities that were initially planned in the form of field visits to be shifted to online interviews. This activity involved the Department of Population and Civil Registration of each district/city as the primary resource person.

The study indicators ${ }^{5}$ at the regional level include data collection teams for vulnerable administrative groups, local government policies to facilitate access, service innovation, the readiness of infrastructure and assistant staff, reference information on requirements and procedures, socialization, advocacy, and education, as well as integration of population document services with integrated service.

According to the indicator variables that have been set for the regional level, the results will be explained in detail in Table 5-12.

\subsubsection{Policies for Facilitating Access}

Table 5. Results Studies of Policy for Facilitating Access in 5 Study Areas

\begin{tabular}{|l|l|}
\hline Region Studies & Results Studies \\
\hline Palu City. & $\begin{array}{l}\text { Palu City has a policy of opening post-disaster administrative } \\
\text { services at evacuation posts for 24 hours, assisted by the } \\
\text { Central Government (Directorate General of Population and } \\
\text { Civil Registration of the Ministry of Home Affairs) and the } \\
\text { Provincial Government (Department of Population and Civil } \\
\text { Registration of Central Sulawesi Province). }\end{array}$ \\
\hline
\end{tabular}

\footnotetext{
${ }^{4}$ Surat Pertanggungjawaban Mutlak (SPTJM) is a Statement of Absolute Responsibility made by the person concerned or his guardian or applicant as the truth with full responsibility known to 2 (two) witnesses.

${ }_{5}^{5}$ (Presidential Decree No. 12 of 2020 concerning the Determination of Non-Natural Disasters Spreading Coronavirus Diseases 2019 (COVID-19) as National Disasters., 2020)
} 


\begin{tabular}{|c|c|}
\hline Bantul District. & $\begin{array}{l}\text { Bantul Regency formed a Technical Team for CRVS } \\
\text { Vulnerable Population Data Collection based on the Decree of } \\
\text { the Head of the Bantul Regency Population and Civil } \\
\text { Registration Office Number 12A } 2017 \text {. }\end{array}$ \\
\hline Muaro Jambi District. & $\begin{array}{l}\text { Muaro Jambi Regency does not yet have a policy that makes } \\
\text { it Suku Anak Dalam easier to obtain legal identity documents. }\end{array}$ \\
\hline East Sumba District. & $\begin{array}{l}\text { East Sumba Regency has a policy for recording marriage and } \\
\text { birth services for followers of the Marapu faith, by } \\
\text { Government Regulation Number } 40 \text { of } 2019 \text { concerning the } \\
\text { Implementation of Law Number } 23 \text { of } 2006 \text { concerning } \\
\text { Population Administration as amended by Law Number } 24 \text { of } \\
2013 \text { concerning Amendments to Law Number } 23 \text { of } 2006 \\
\text { concerning Population Administration and the decision of the } \\
\text { Constitutional Court Number 97/PUU-XIV/2016. }\end{array}$ \\
\hline $\begin{array}{l}\text { DKI Jakarta Province } \\
\text { and Surabaya City. }\end{array}$ & $\begin{array}{l}\text { DKI Jakarta Province has policies to facilitate access through } \\
\text { regulations: } \\
\text { The Governor of the Special Capital Region Regulation } \\
\text { Number } 2 \text { of } 2018 \text { about Integrated Services for Social } \\
\text { Assisted Residents in Social Institutions; } \\
\text { Regulation of the Governor of the Special Capital } \\
\text { Region of Jakarta Number } 110 \text { of } 2018 \text { concerning } \\
\text { Improving the Quality of Population Administration } \\
\text { Services. } \\
\text { Regulation of the Governor of the Special Capital } \\
\text { Region of Jakarta Number } 33 \text { of } 2020 \text { concerning the } \\
\text { Implementation of Large-Scale Social Restrictions in } \\
\text { Handling Corona Virus Disease } 2019 \text { (COVID-19) in } \\
\text { Jakarta Province. } \\
\text { Decree of the Regional Secretary of the Special Capital } \\
\text { Region of Jakarta Number 96 of } 2019 \text { concerning } \\
\text { Standard Operational Procedures for Registration of } \\
\text { National Health Insurance (BPJS Kesehatan) for Social } \\
\text { Assisted Citizens. } \\
\text { Cooperation Agreement between Department of } \\
\text { Population and Civil Registration (Disdukcapil) and the } \\
\text { Office of Social Affairs, Health Office, Education Office, } \\
\text { BPJS Kesehatan, Tourism and Culture Office, } \\
\text { Manpower and Transmigration Office, Cooperative } \\
\text { Office, Micro, Small and Medium Enterprises and } \\
\text { Trade, Industry and Energy Office, DPPAPP , and } \\
\text { DKPKP7. } \\
\text { Decree of the Head of Disdukcapil Number } 23 \text { of } 2020 \\
\text { concerning Procedures for Implementing Population } \\
\text { Administration Services in DKI Jakarta Province During the } \\
\text { PSBB Period. }\end{array}$ \\
\hline
\end{tabular}

\footnotetext{
${ }^{6}$ Dinas Pemberdayaan Perlindungan Anak dan Pengendalian Penduduk: the agency related to community, women empowerment, and family planning.

${ }^{7}$ Dinas Ketahanan Pangan, Kelautan dan Pertanian: the agency in charge of food security, maritime affairs, fisheries, agriculture, animal husbandry, and animal health
} 


\begin{tabular}{|l|l|}
\hline Surabaya City has the policy to facilitate access for vulnerable \\
groups through the Surabaya City Regional Regulation \\
Number o6 of 2019 concerning the Implementation of \\
Population Administration Article 38.
\end{tabular}

\subsubsection{Formation of the Population Administration Vulnerable Groups Data Collection Team}

Table 6. Formation of Population Administration Vulnerable Groups Data Collection

Team in 5 Study Areas

\begin{tabular}{|c|c|}
\hline Region Studies. & Results Studies. \\
\hline Palu City. & $\begin{array}{l}\text { Palu City has formed the Population Administration Vulnerable } \\
\text { Groups Data Collection Team involving Regional Apparatus } \\
\text { Organizations (OPD) for handling and collecting data on disaster } \\
\text { victims who move. (with the distribution of handling and data } \\
\text { collection areas). }\end{array}$ \\
\hline Bantul District. & $\begin{array}{l}\text { Bantul District has formed the Population Administration } \\
\text { Vulnerable Groups Data Collection Team involving OPDs such } \\
\text { as the Office of Population Control and Family Planning, the } \\
\text { Social Service Office, and all sub-districts in Bantul. Since 2017, } \\
\text { the Population Administration Vulnerable Groups Data } \\
\text { Collection Team has recorded } 24 \text { nursing homes; held } \\
\text { socialization and technical guidance on data collection of } \\
\text { vulnerable populations to } 933 \text { hamlets; and routine coordination } \\
\text { with the hamlet, village, and sub-district. }\end{array}$ \\
\hline $\begin{array}{l}\text { Muaro } \\
\text { District. }\end{array}$ & $\begin{array}{l}\text { Muaro Jambi District has not yet formed the Population } \\
\text { Administration Vulnerable Groups Data Collection Team. }\end{array}$ \\
\hline East Sumba District. & $\begin{array}{l}\text { East Sumba District has not formed the Population } \\
\text { Administration Vulnerable Groups Data Collection Team } \\
\text { because of local budget limitations (APBD). }\end{array}$ \\
\hline \multirow[t]{2}{*}{$\begin{array}{lr}\text { DKI } & \text { Jakarta } \\
\text { Province } & \text { and } \\
\text { Surabaya City. }\end{array}$} & $\begin{array}{l}\text { DKI Jakarta Province has formed the Population Administration } \\
\text { Vulnerable Groups Data Collection Team through DKI Jakarta } \\
\text { Governor Regulation Number } 2 \text { of } 2018 \text { about Integrated } \\
\text { Population Administration Vulnerable Groups Services for } \\
\text { Social Assisted Residents in Social Institutions. The are several } \\
\text { OPDs involved, such as the Population and Civil Registration } \\
\text { Office, the Social Service, the Health Officer, the Education } \\
\text { Officer, the Communications, Information, and Statistics Office, } \\
\text { and the Regional IV BPJS Health Division. }\end{array}$ \\
\hline & $\begin{array}{l}\text { The Surabaya City did not form the Population Administration } \\
\text { Vulnerable Groups Data Collection Team because the main tasks } \\
\text { and functions were considered to be inherent in the Department } \\
\text { of Population and Civil Registration (Disdukcapil), thus data } \\
\text { collection on the Population Administration Vulnerable Groups } \\
\text { was carried out through routine coordination between OPDs such } \\
\text { as the Social Service, DP5A, and disaster management teams }\end{array}$ \\
\hline
\end{tabular}




\begin{tabular}{|l|l}
\hline & $\begin{array}{l}\text { (Human Development and Culture Agency, and } \\
\text { Bakesbanglinmas). }\end{array}$ \\
\hline
\end{tabular}

\subsubsection{Service Innovation to Reach Vulnerable Groups in Population Administration}

Table 7. Service Innovation to Reach Population Administration Vulnerable Groups in 5 Study Areas

\begin{tabular}{|c|c|}
\hline Region Studies. & Results Studies. \\
\hline Palu City. & $\begin{array}{l}\text { Palu City made several innovations to reach population } \\
\text { administration vulnerable groups, i.e: } \\
\text { - } \\
\text { Issuance and amendment of residence documents } \\
\text { without completing the requirements (if the required } \\
\text { documents are damaged/lost due to disaster). For E- } \\
\text { KTP and NIK documents, verification is only through } \\
\text { interviews and biometric data pairing from SIAK. As } \\
\text { for the Death Certificate, it is only by signing the } \\
\text { SPTJM. } \\
\text { - Formation of cross-OPD team Whatsapp groups for } \\
\text { coordination purposes. } \\
\text { Provision of inclusive special services. } \\
\text { - Service approach at the sub-district and village levels } \\
\text { (provide recording facilities and computers in } 4 \text { main } \\
\text { sub-districts, namely West Palu, East Palu, South } \\
\text { Palu, and Tawaeli). } \\
\text { Cooperation with } \\
\text { Organizations (OXFAM and UNICEF) for inclusive } \\
\text { services at seven evacuation points. } \\
\text { Cooperation with health facilities for issuing birth } \\
\text { certificates. Also with places/officers of worship for of } \\
\text { marriages and divorces registration. } \\
\text { - Cooperation with the Department of Social Affairs to } \\
\text { verify personal data of social assistance and life } \\
\text { insurance (Jadup) beneficiaries after a disaster. } \\
\text { populations in CRVS, Palu faces challenges: total power outages } \\
\text { after the disaster, limited recording and printing equipment due } \\
\text { to damage and theft, limited budget compared to service needs } \\
\text { in each region, lack of infrastructure for pick-up services. }\end{array}$ \\
\hline Bantul District. & $\begin{array}{l}\text { The innovations to reach population administration vulnerable } \\
\text { groups made by Bantul District are: } \\
\text { - Morolego (pick-up service to people's homes, } \\
\text { orphanages, schools, correctional institutions, and }\end{array}$ \\
\hline
\end{tabular}




\begin{tabular}{|c|c|}
\hline & $\begin{array}{l}\text { other abandoned people's locations after receiving data } \\
\text { from the hamlet/Social Service). } \\
\text { - Situpat/Siji Untuk Papa (Vulnerable residents } \\
\text { immediately get } 4 \text { (four) documents at once: National } \\
\text { Identity Number (NIK), Family Card/KK, Birth } \\
\text { Certificate, and Child Identity Card/KIA). } \\
\text { - Go AKTA/KIA (Services for vulnerable people } \\
\text { directly obtaining a Family Card, Birth Certificate, and } \\
\text { MCH). } \\
\text { - Dukcapil Smart application. } \\
\text { The challenges faced by Bantul District related to the } \\
\text { implementation of Service Innovations that Reach Population } \\
\text { Administration Vulnerable Groups are: limited access to reach } \\
\text { location points, inadequate internet network, difficulty in } \\
\text { serving population documents for neglected residents with } \\
\text { mental disorders, high mobility of abandoned people, limited } \\
\text { budget and is optimized only for service support costs. }\end{array}$ \\
\hline Muaro Jambi District. & $\begin{array}{l}\text { Innovations carried out by Muaro Jambi District to reach } \\
\text { population administration vulnerable groups in the form of } \\
\text { initial data collection on the existence of the Anak Dalam Tribe } \\
\text { by involving the Village Head, religious leaders, the Community } \\
\text { Security and Order Agency; as well as online-based population } \\
\text { document services through the Whatsapp application. } \\
\text { The challenges faced by Muaro Jambi District in } \\
\text { implementation are that some members of the Anak Dalam } \\
\text { Tribe denied taking photos for recording purposes. Pick-up } \\
\text { activity to the location often does not according to plan due to } \\
\text { the uncertain position of the Anak Dalam Tribe, as well as } \\
\text { budget constraints. }\end{array}$ \\
\hline East Sumba District. & $\begin{array}{l}\text { East Sumba District made innovations to Reach Population } \\
\text { Administration Vulnerable Groups by providing pick-up } \\
\text { services at the sub-district and village levels, collaborating with } \\
\text { the Wali Alti Foundation and health facilities. } \\
\text { The challenges are the limited mode of transportation related } \\
\text { to the wide and difficult geographical conditions, inadequate } \\
\text { internet network, limited budget, inadequate building facilities, } \\
\text { and no third party that facilitates the issuance of customary } \\
\text { marriage records in the Marapu Community because most of } \\
\text { the Marapu people are illiterate. }\end{array}$ \\
\hline
\end{tabular}




\begin{tabular}{|c|c|}
\hline $\begin{array}{l}\text { DKI Jakarta Province } \\
\text { and Surabaya City. }\end{array}$ & $\begin{array}{l}\text { Service innovations carried out by DKI Jakarta Province to } \\
\text { Reach Population Administration Vulnerable Groups are: } \\
\text { - The 'Dokter Perkasa' application (Integrated Document } \\
\text { Full of Love) for submitting a new National ID Number } \\
\text { application has moved to come for inmates at Social } \\
\text { Institutions. } \\
\text { - 'Data Warga' application for non-permanent data } \\
\text { collection of DKI Jakarta residents at the Neighborhood } \\
\text { RT and RW levels. } \\
\text { - Application 'Alpukat Betawi' for submission of residence } \\
\text { document services at the resident's house (pick up } \\
\text { services). } \\
\text { - Residential document services through social media. } \\
\text { Post-disaster administrative vulnerable services through } \\
\text { integrating population data with disaster management } \\
\text { data. } \\
\text { Service innovations carried out by the Surabaya City are: } \\
\text { - Klampid' website and 'Pandawa Lima' application for } \\
\text { online population document management. } \\
\text { E-KTP recording queue application to reduce queues. } \\
\text { - Online marriage registration using the Zoom } \\
\text { application. } \\
\text { 'Surabaya E-ID' application to check the status of } \\
\text { residence document submission. } \\
\text { complaints or questions related to population } \\
\text { document services. }\end{array}$ \\
\hline
\end{tabular}

The innovations carried out by the Province of DKI Jakarta, and the City of Surabaya are generally online-based population document services. This is by the instructions of the Circular Letter of the Directorate General of Population and Civil Registry Number 43.1/2978/Dukcapil concerning Population Document Services via Whatsapp-based Online or the website. The challenges faced by these two regions in realizing online-based services are that not all residents are ready to understand online-based technology, low literacy, still low awareness of population administration, very high mobility of vulnerable populations, and the unavailability of 'Machine to Machine devices. 


\subsubsection{Readiness of Infrastructure Facilities and Service Officers}

Table 8. Readiness of Infrastructure Facilities and Service Officers in 5 Study Areas

\begin{tabular}{|c|c|}
\hline Region Studies. & Results Studies. \\
\hline Palu City. & $\begin{array}{l}\text { The readiness of infrastructure in Palu City is not sufficient } \\
\text { in terms of recording and printing equipment, computers, } \\
\text { and E-KTP forms. At the same time, the readiness of Service } \\
\text { Officers is inadequate due to the limited number of } \\
\text { Population and Civil Registration Agency Officers because } \\
\text { of disaster. }\end{array}$ \\
\hline Bantul District. & $\begin{array}{l}\text { Bantul District has an adequate infrastructure } \\
\text { (representative service building) and transportation (two } \\
\text { cars for mobile services, one operational car with recording } \\
\text { equipment, two motorbikes). Also, it has adequate } \\
\text { experienced Population and Civil Registration Agency } \\
\text { Officers are (have been technical employees for many years } \\
\text { and follow technical guidance regularly). }\end{array}$ \\
\hline Muaro Jambi District. & $\begin{array}{l}\text { Muaro Jambi District has not a representative operational } \\
\text { vehicle for mobilization (with certain geographical } \\
\text { conditions). Also, there is a limited number of officers. }\end{array}$ \\
\hline East Sumba District. & $\begin{array}{l}\text { Infrastructure in East Sumba District is not adequate, such } \\
\text { as buildings are not comfortable for services, insufficient } \\
\text { electricity, limited computer/laptop/printer equipment and } \\
\text { old specifications, and limited transportation infrastructure } \\
\text { (broken official vehicles). There is a limited number of } \\
\text { service officers and not highly educated. }\end{array}$ \\
\hline $\begin{array}{l}\text { DKI Jakarta Province } \\
\text { and Surabaya City. }\end{array}$ & $\begin{array}{l}\text { DKI Jakarta Province and Surabaya City have adequate } \\
\text { infrastructures, such as the availability of computers, tabs, } \\
\text { scanners, vehicles, and E-KTP forms. There are adequate } \\
\text { number and performance skills of employees. }\end{array}$ \\
\hline
\end{tabular}




\subsubsection{Reference Information on Terms and Procedures}

Table 9. Results Studies of Reference Information on Requirements and Procedures in the 5 Study Areas

\begin{tabular}{|c|c|}
\hline Region Studies. & Results Studies. \\
\hline Palu City. & $\begin{array}{l}\text { Information on the Requirements and Procedures for } \\
\text { Obtaining Population Documents in Palu City is conveyed } \\
\text { through socialization. This process is carried out when } \\
\text { officers go to the field with NGO partners (UNICEF } \\
\text { through Karampuang Foundation, ACT, WVI, OXFAM, } \\
\text { and PKBI); broadcast interactive interviews and dialogues } \\
\text { by local TV stations as print and electronic media } \\
\text { coverage. }\end{array}$ \\
\hline Bantul District. & $\begin{array}{l}\text { In Bantul District, Information on the Requirements and } \\
\text { Procedures for Managing Population Documents is } \\
\text { conveyed through indirect communication media } \\
\text { (pamphlets, posters, official websites, social media, } \\
\text { guidebooks) and direct communication media } \\
\text { (socialization/field visits). }\end{array}$ \\
\hline Muaro Jambi District. & $\begin{array}{l}\text { Information on the Requirements and Procedures for } \\
\text { Management of Population Documents in Muaro Jambi } \\
\text { District was conveyed through direct socialization from } \\
\text { religious leaders, Village Heads, and Population and Civil } \\
\text { Registration Agency officers of Muaro Jambi District; and } \\
\text { social media (Facebook Application). }\end{array}$ \\
\hline East Sumba District. & $\begin{array}{l}\text { In East Sumba District, Information on the Requirements } \\
\text { and Procedures for Administration of Population } \\
\text { Documents is conveyed through direct socialization } \\
\text { during field visits and notifications through sub- } \\
\text { district/village officials. }\end{array}$ \\
\hline $\begin{array}{l}\text { DKI Jakarta Province and } \\
\text { Surabaya City. }\end{array}$ & $\begin{array}{l}\text { Especially for DKI Jakarta Province and Surabaya City, } \\
\text { Information on the Requirements and Procedures for } \\
\text { Managing Population Documents is submitted through } \\
\text { pamphlets, posters, websites/blogs, guidebooks, and } \\
\text { social media (Twitter and Instagram). }\end{array}$ \\
\hline
\end{tabular}




\subsubsection{Socialization, Advocacy, Service Education, and Enthusiasm of Population Administration Vulnerable Groups}

Table 10. Results Studies of Socialization, Advocacy, Service Education and Enthusiasm of Population Administration Vulnerable Groups in 5 Study Areas

\begin{tabular}{|c|c|}
\hline Region Studies. & Results Studies. \\
\hline Palu City. & $\begin{array}{l}\text { Socialization, Advocacy, and Service Education are carried } \\
\text { out by Disdukcapil Officers and related OPDs in Palu City, } \\
\text { such as the Social Service. The enthusiasm of the Vulnerable } \\
\text { Population Administration is outstanding because the } \\
\text { service makes it easy to obtain residence documents as the } \\
\text { main requirement for receiving social assistance. }\end{array}$ \\
\hline Bantul District. & $\begin{array}{l}\text { Disdukcapil officers of Bantul Regency conduct outreach, } \\
\text { Advocacy, and Service Education in Bantul Regency to } \\
\text { orphanages throughout the region. The enthusiasm of the } \\
\text { Vulnerable Population Adminduk is outstanding. The } \\
\text { hamlets and orphanages have sent data on the vulnerable } \\
\text { population from their respective areas to process their } \\
\text { residency documents later. In } 2020 \text { there will be } 50 \text { files of } \\
\text { vulnerable administrative residents whose requirements } \\
\text { have been completed to make population documents. }\end{array}$ \\
\hline Muaro Jambi District. & $\begin{array}{l}\text { Muaro Jambi Regency Officers accompanied by Village } \\
\text { Heads and religious instructors doing Socialization, } \\
\text { Advocacy, and Education Services in Muaro Jambi Regency } \\
\text { were carried out because they often interacted with the Anak } \\
\text { Dalam Tribe. Therefore, the presence of officers can be well } \\
\text { received. The enthusiasm of the Orang Rimba in managing } \\
\text { population documents is also quite good. }\end{array}$ \\
\hline East Sumba District. & $\begin{array}{l}\text { In East Sumba Regency, Disdukcapil Officers do } \\
\text { Socialization, Advocacy, and Education Services by } \\
\text { involving sub-district officials, village officials, community } \\
\text { leaders, religious leaders, educators, and the general public. } \\
\text { Also by doing mobile services to the villages directly. The } \\
\text { enthusiasm of the Marapu Believers is considered quite } \\
\text { good, and many of them have registered their marriages. }\end{array}$ \\
\hline $\begin{array}{l}\text { DKI Jakarta Province } \\
\text { and Surabaya City. }\end{array}$ & $\begin{array}{l}\text { Disdukcapil Officers of DKI Jakarta Province carry out } \\
\text { socialization, Advocacy, and Service Education by posting } \\
\text { information at service counters, dissemination through } \\
\text { social media and virtual meetings, online services via } \\
\text { electronic mail and smartphones, and collaboration with } \\
\text { related OPDs. In the city of Surabaya, this activity is carried } \\
\text { out through the empowerment of sub-districts and sub- } \\
\text { districts. The enthusiasm of the administration's vulnerable } \\
\text { population towards the management of population } \\
\text { documents in the two areas is outstanding. }\end{array}$ \\
\hline
\end{tabular}




\subsubsection{Integrated Services}

Table 11. Integrated Services in 5 Study Areas

\begin{tabular}{|c|c|}
\hline Region Studies. & Result Studies. \\
\hline Palu City. & $\begin{array}{l}\text { Population Service in Palu City has been integrated with } \\
\text { Social Service to verify and validate disaster victims' life } \\
\text { insurance assistance. Then, Regional Employment Agency } \\
\text { used this service for issuing death certificates for } \\
\text { employees. The Regional Development Planning Agency } \\
\text { (Bappeda) and the Regional Disaster Management Agency } \\
\text { (BPBD) were used to verify and validate data on assistance } \\
\text { and stimulant funds disbursement for temporary shelter } \\
\text { and permanent shelter. Education Office used for } \\
\text { verification and validation of assistance for disaster-affected } \\
\text { school children. }\end{array}$ \\
\hline Bantul District. & $\begin{array}{l}\text { Population Service in Bantul District has been integrated } \\
\text { with other Regional Government Organizations, including } \\
\text { the Social Service for verification and validation of social } \\
\text { assistance provision for vulnerable populations; and the } \\
\text { Education Office used for school registration for neglected } \\
\text { child residents. }\end{array}$ \\
\hline Muaro Jambi District. & $\begin{array}{l}\text { Population Service in Muaro Jambi District has not been } \\
\text { integrated with other Regional Government } \\
\text { Organizations. }\end{array}$ \\
\hline East Sumba District. & $\begin{array}{l}\text { Population Service in Muaro Jambi District has not been } \\
\text { integrated with other Regional Government } \\
\text { Organizations. }\end{array}$ \\
\hline $\begin{array}{l}\text { DKI Jakarta Province and } \\
\text { Surabaya City. }\end{array}$ & $\begin{array}{l}\text { Population Services in DKI Jakarta Province and Surabaya } \\
\text { City have been integrated with other Regional } \\
\text { Government Organizations. In DKI Jakarta Province, the } \\
\text { services are integrated with BPJS-Health. It is used for data } \\
\text { verification on prospective recipients of social assistance, } \\
\text { educational assistance, and assistance for entrepreneurship } \\
\text { programs, and it is utilized for "Rusunawa" services. } \\
\text { Meanwhile, in Surabaya City, Population Service is } \\
\text { integrated with other public services through the main } \\
\text { website "Surabaya Single Window." }\end{array}$ \\
\hline
\end{tabular}




\subsubsection{Findings}

Table 12. Findings in 5 Study Areas

\begin{tabular}{|l|l|}
\hline Region Studies. & Result Studies. \\
\hline Palu City. & $\begin{array}{l}\text { Public services for natural disasters victims in Palu City } \\
\text { are carried out three days after the disaster occurs to } \\
\text { time lag recovery. The new Family Card/KTP cannot } \\
\text { be given to permanent residents because there is no clear } \\
\text { address such as street name and RT/RW. The issuance } \\
\text { of population documents also provided for non-Palu } \\
\text { residents who were affected by the disaster and had } \\
\text { difficulty returning to their origin. }\end{array}$ \\
\hline Bantul District. & $\begin{array}{l}\text { Bantul District coordinates with the neglected people } \\
\text { management or the hamlet in determining neglected } \\
\text { people's domicile. Many Bantul District Disdukcapil } \\
\text { officers have retired or been transferred. }\end{array}$ \\
\hline Muaro Jambi District. & $\begin{array}{l}\text { The Anak Dalam Tribe has been able to adapt as } \\
\text { residents with a semi-nomadic life. In addition, the Suku } \\
\text { Anak Dalam have never made changes to the identity } \\
\text { data and did not understand the urgency of having a } \\
\text { population registration document. }\end{array}$ \\
\hline East Sumba District. & $\begin{array}{l}\text { The majority of the Marapu Community have low } \\
\text { education, thus it affects awareness in managing } \\
\text { population documents. In addition, many residents of }\end{array}$ \\
East Sumba change their element data to get \\
financial/social supports.
\end{tabular}

Based on analysis of these indicators, it is known there are three good practices in data collection and issuance of population documents for population administration vulnerable groups, i.e.: 1) Vulnerable groups data collection; 2) Administrative services outreach to vulnerable groups; 3) Vulnerable groups data utilization for program planning. To sharpen the definition of vulnerable groups to have an impact on outreach to these vulnerable groups, a complete and specific technical regulation is needed. The central government needs to make implementation guidelines based on the main regulations that are already in effect as a technical reference for the implementation of services at the regional level. The central government needs to make technical guidelines for service implementation at the regional level based on the main regulations. Meanwhile at the regional level, to eliminate discrimination based on social identity, service providers need to overcome stigma by providing responsive and inclusive services. In addition, it is necessary to mainstream the removal of stigma at every level of government. (KOMPAK \& PUSKAPA, 2020) 


\section{Conclusion and Recommendation}

\subsection{Conclusions}

1) The Central Government has made policies that make it easier for the vulnerable population to access administrative services through Presidential Regulation Number 62 of 2019 about the AKPSH National Strategy and Minister of Home Affairs Regulation Number 96 of 2019 about Population Data Collection and Issuance of Population Documents for Population Administration Vulnerable Groups and Special Groups.

2) There are still exist Population Administration Vulnerable Groups that have not been accommodated in the regulations governing vulnerable populations, such as Presidential Regulation 62/2019 and Minister of Home Affairs 96/2019.

3) The Technical Guidelines for Population Services have been clearly and detailed in the law thus it can be served various types of administrative vulnerabilities.

4) The overall comparison of monitoring indicators between regions, in a nutshell, is shown in Table 13. 
Table 13. Comparison of Study Results per Indicator in 5 Regions

\begin{tabular}{|c|c|c|c|c|c|}
\hline \multirow{2}{*}{$\begin{array}{l}\text { Monitoring } \\
\text { Study } \\
\text { Indicators }\end{array}$} & \multicolumn{5}{|c|}{ Area } \\
\hline & Palu City & Bantul District & $\begin{array}{l}\text { Muaro Jambi } \\
\text { District }\end{array}$ & $\begin{array}{l}\text { East Sumba } \\
\text { District }\end{array}$ & $\begin{array}{c}\text { DKI Jakarta Province and } \\
\text { Surabaya City }\end{array}$ \\
\hline $\begin{array}{l}\text { Policies for } \\
\text { Easy Access. }\end{array}$ & $\begin{array}{l}\text { Have the policy to } \\
\text { facilitate access in } \\
\text { the form of } \\
\text { Population } \\
\text { Administration } \\
\text { Services at the 24- } \\
\text { hour Disaster Post. }\end{array}$ & $\begin{array}{l}\text { Have the policy to } \\
\text { facilitate access in } \\
\text { the form of the } \\
\text { formation of a } \\
\text { Technical Team for } \\
\text { Data Collection of } \\
\text { Population } \\
\text { Administration } \\
\text { Vulnerable Groups. }\end{array}$ & $\begin{array}{l}\text { Don't have the } \\
\text { policy to make } \\
\text { access easier. }\end{array}$ & $\begin{array}{l}\text { Don't have the } \\
\text { policy to make } \\
\text { access easier. }\end{array}$ & $\begin{array}{l}\text { DKI Jakarta has the policy } \\
\text { to facilitate access through } \\
\text { Governor Regulation } \\
\text { 2/2018, Governor } \\
\text { Regulation } 110 / 2018, \\
\text { Decree of Department of } \\
\text { Population and Civil } \\
\text { Registration (Disdukcapil) } \\
\text { 23/2020. } \\
\text { Surabaya City has the } \\
\text { policy to facilitate access in } \\
\text { the form of Surabaya Local } \\
\text { Regulation (Perda) 6/2019. }\end{array}$ \\
\hline $\begin{array}{c}\text { Formation of } \\
\text { the Population } \\
\text { Administration } \\
\text { Vulnerable } \\
\text { Groups Data } \\
\text { Collection } \\
\text { Team. }\end{array}$ & $\begin{array}{c}\text { Has formed a Cross- } \\
\text { Regional Apparatus } \\
\text { Organization (OPD) } \\
\text { Population } \\
\text { Administration } \\
\text { Vulnerable Groups } \\
\text { Data Collection } \\
\text { Team. }\end{array}$ & $\begin{array}{c}\text { Has formed a Cross- } \\
\text { Regional Apparatus } \\
\text { Organization (OPD) } \\
\text { Population } \\
\text { Administration } \\
\text { Vulnerable Groups } \\
\text { Data Collection } \\
\text { Team. }\end{array}$ & $\begin{array}{l}\text { Has not formed a } \\
\text { Population } \\
\text { Administration } \\
\text { Vulnerable } \\
\text { Groups Data } \\
\text { Collection Team. }\end{array}$ & $\begin{array}{c}\text { Has not formed a } \\
\text { Population } \\
\text { Administration } \\
\text { Vulnerable Groups } \\
\text { Data Collection } \\
\text { Team. }\end{array}$ & $\begin{array}{l}\text { DKI Jakarta has formed a } \\
\text { Cross-Regional Apparatus } \\
\text { Organization (OPD) } \\
\text { Population Administration } \\
\text { Vulnerable Groups Data } \\
\text { Collection Team. } \\
\text { Surabaya has not formed a } \\
\text { Population Administration } \\
\text { Vulnerable Groups Data } \\
\text { Collection Team. }\end{array}$ \\
\hline $\begin{array}{c}\text { Service } \\
\text { Innovation to } \\
\text { Reach }\end{array}$ & $\begin{array}{l}\text { Have Service } \\
\text { Innovations in the } \\
\text { form of publishing }\end{array}$ & $\begin{array}{c}\text { Have Service } \\
\text { Innovation in the } \\
\text { form of Morolego }\end{array}$ & $\begin{array}{l}\text { Have Service } \\
\text { Innovations in the } \\
\text { form of data }\end{array}$ & $\begin{array}{l}\text { Have Service } \\
\text { Innovations in the } \\
\text { form of pick-up }\end{array}$ & $\begin{array}{l}\text { Have Service Innovations in } \\
\text { the form of: }\end{array}$ \\
\hline
\end{tabular}




\begin{tabular}{|c|c|c|c|c|c|}
\hline $\begin{array}{c}\text { Population } \\
\text { Administration } \\
\text { Vulnerable } \\
\text { Groups. }\end{array}$ & $\begin{array}{c}\text { population } \\
\text { documents without } \\
\text { requirements, } \\
\text { collaboration with } \\
\text { other NGOs/Health } \\
\text { Facilities/OPD, } \\
\text { service approaches to } \\
\text { sub- } \\
\text { districts/villages. }\end{array}$ & $\begin{array}{c}\text { (pick-up services) } \\
\text { program, Situpat, Go } \\
\text { AKTA/KIA, } \\
\text { Dukcapil Smart } \\
\text { Application. }\end{array}$ & $\begin{array}{l}\text { collection on the } \\
\text { existence of the } \\
\text { Suku Anak Dalam } \\
\text { and online-based } \\
\text { services. }\end{array}$ & $\begin{array}{l}\text { services in sub- } \\
\text { districts/villages } \\
\text { (cooperation with } \\
\text { foundations and } \\
\text { health facilities). }\end{array}$ & $\begin{array}{l}\text { DKI Jakarta: Perkasa } \\
\text { Doctor Application, Citizen } \\
\text { Data, Alpukat Betawi. } \\
\text { Surabaya: Klampid Website, } \\
\text { Pandawa Lima Application, } \\
\text { E-KTP Recording Queue } \\
\text { Application, Surabaya E-ID. }\end{array}$ \\
\hline $\begin{array}{c}\text { Readiness of } \\
\text { Facilities and } \\
\text { Service } \\
\text { Officers. }\end{array}$ & $\begin{array}{c}\text { The readiness of } \\
\text { infrastructure and } \\
\text { human resources is } \\
\text { not sufficient. }\end{array}$ & $\begin{array}{c}\text { The readiness of } \\
\text { infrastructure and } \\
\text { human resources is } \\
\text { adequate. }\end{array}$ & $\begin{array}{l}\text { The readiness of } \\
\text { infrastructure and } \\
\text { human resources } \\
\text { is not sufficient. }\end{array}$ & $\begin{array}{c}\text { The readiness of } \\
\text { infrastructure and } \\
\text { human resources is } \\
\text { not sufficient. }\end{array}$ & $\begin{array}{l}\text { The readiness of } \\
\text { infrastructure and human } \\
\text { resources is adequate. }\end{array}$ \\
\hline $\begin{array}{c}\text { Reference } \\
\text { Information } \\
\text { about Terms } \\
\text { and } \\
\text { Procedures. }\end{array}$ & $\begin{array}{c}\text { Reference } \\
\text { Information on } \\
\text { Requirements and } \\
\text { Procedures through } \\
\text { direct socialization } \\
\text { and news } \\
\text { broadcasting by TV. }\end{array}$ & $\begin{array}{l}\text { Referral for } \\
\text { information on } \\
\text { requirements and } \\
\text { procedures through } \\
\text { direct socialization, } \\
\text { pamphlets, posters, } \\
\text { brochures, etc. }\end{array}$ & $\begin{array}{l}\text { Reference for } \\
\text { Information on } \\
\text { Requirements and } \\
\text { Procedures } \\
\text { through } \\
\text { socialization from } \\
\text { religious leaders } \\
\text { and social media. }\end{array}$ & $\begin{array}{c}\text { Referral for } \\
\text { Information on } \\
\text { Requirements and } \\
\text { Procedures through } \\
\text { direct socialization. }\end{array}$ & $\begin{array}{l}\text { Reference Information } \\
\text { about the Terms and } \\
\text { Procedures through } \\
\text { pamphlets, posters, } \\
\text { websites, social media. }\end{array}$ \\
\hline $\begin{array}{l}\text { Socialization, } \\
\text { Advocacy, and } \\
\text { Service } \\
\text { Education, and } \\
\text { Vulnerable } \\
\text { Population } \\
\text { Enthusiasm }\end{array}$ & $\begin{array}{c}\text { Socialization, } \\
\text { Advocacy, and } \\
\text { Education Services } \\
\text { are carried out by } \\
\text { related officers and } \\
\text { Regional } \\
\text { Government } \\
\text { Organization/OPD, } \\
\text { Vulnerable } \\
\text { Population }\end{array}$ & $\begin{array}{c}\text { Socialization, } \\
\text { Advocacy, and } \\
\text { Education Services } \\
\text { are carried out by } \\
\text { officers to the } \\
\text { orphanage, } \\
\text { Vulnerable } \\
\text { Population } \\
\text { Enthusiasm is quite } \\
\text { good }\end{array}$ & $\begin{array}{c}\text { Socialization, } \\
\text { Advocacy, and } \\
\text { Education Services } \\
\text { are carried out by } \\
\text { officers } \\
\text { accompanied by } \\
\text { the Village Head } \\
\text { and religious } \\
\text { leaders, } \\
\text { Vulnerable } \\
\text { Population }\end{array}$ & $\begin{array}{c}\text { Socialization, } \\
\text { Advocacy, and } \\
\text { Education Services } \\
\text { are carried out by } \\
\text { officers } \\
\text { accompanied by } \\
\text { village officials, } \\
\text { community leaders, } \\
\text { and religious } \\
\text { leaders. The } \\
\text { enthusiasm of the }\end{array}$ & $\begin{array}{l}\text { Socialization, Advocacy, and } \\
\text { Education Services are } \\
\text { carried out by officers } \\
\text { through social media and } \\
\text { electronic mail, Vulnerable } \\
\text { population's Enthusiasm is } \\
\text { considered quite good. }\end{array}$ \\
\hline
\end{tabular}




\begin{tabular}{|c|c|c|c|c|c|}
\hline & $\begin{array}{l}\text { Enthusiasm is quite } \\
\text { good. }\end{array}$ & & $\begin{array}{l}\text { Enthusiasm is } \\
\text { quite good. }\end{array}$ & $\begin{array}{c}\text { vulnerable } \\
\text { population is quite } \\
\text { good. }\end{array}$ & \\
\hline $\begin{array}{l}\text { Integrated } \\
\text { Service }\end{array}$ & $\begin{array}{c}\text { Integrated Service } \\
\text { has been integrated } \\
\text { with other Regional } \\
\text { Government } \\
\text { Organization (OPD). }\end{array}$ & $\begin{array}{c}\text { Integrated Service } \\
\text { has been integrated } \\
\text { with other Regional } \\
\text { Government } \\
\text { Organization (OPD). }\end{array}$ & $\begin{array}{c}\text { Integrated Service } \\
\text { is not yet } \\
\text { integrated with } \\
\text { other Regional } \\
\text { Government } \\
\text { Organization } \\
\text { (OPD). }\end{array}$ & $\begin{array}{c}\text { Integrated Service } \\
\text { is not yet integrated } \\
\text { with other Regional } \\
\text { Government } \\
\text { Organization } \\
\text { (OPD). }\end{array}$ & $\begin{array}{l}\text { Integrated Service has been } \\
\text { integrated with other } \\
\text { Regional Government } \\
\text { Organization (OPD). }\end{array}$ \\
\hline Finding & $\begin{array}{l}\text { The findings of the } \\
\text { monitoring results } \\
\text { are: Implementation } \\
\text { of post-disaster H+3 } \\
\text { public services, } \\
\text { Family } \\
\text { Card/National } \\
\text { Identity Card cannot } \\
\text { be given to residents } \\
\text { who do not have a } \\
\text { clear address, } \\
\text { issuance of } \\
\text { population } \\
\text { documents for non- } \\
\text { Palu residents. }\end{array}$ & $\begin{array}{l}\text { The findings of the } \\
\text { monitoring results } \\
\text { are Coordination } \\
\text { with the Dukuh } \\
\text { Head to determine } \\
\text { the domiciles of } \\
\text { abandoned people, } \\
\text { and officers who are } \\
\text { retiring/transferring } \\
\text { to other areas. }\end{array}$ & $\begin{array}{l}\text { The findings of } \\
\text { the monitoring } \\
\text { results are: Suku } \\
\text { Anak Dalam have } \\
\text { been able to adapt, } \\
\text { have not } \\
\text { understood the } \\
\text { urgency of } \\
\text { population } \\
\text { documents, and } \\
\text { have never } \\
\text { changed } \\
\text { population data. }\end{array}$ & $\begin{array}{l}\text { The findings of the } \\
\text { monitoring results } \\
\text { are: The Marapu } \\
\text { community does } \\
\text { not understand the } \\
\text { urgency of } \\
\text { population } \\
\text { documents, many } \\
\text { people change } \\
\text { job/professional } \\
\text { data. }\end{array}$ & $\begin{array}{l}\text { The findings of the } \\
\text { monitoring results are: the } \\
\text { involvement of the } \\
\text { Neighborhood Chairman } \\
\text { (Ketua RT), a collaboration } \\
\text { between health facilities and } \\
\text { the police is considered } \\
\text { effective for collecting data } \\
\text { on vulnerable populations. }\end{array}$ \\
\hline
\end{tabular}

\section{Recommendations}

1) Regulatory studies are required to determine vulnerable groups in CRVS classification based on vulnerabilities and barriers.

2) Institutional strengthening is important in outreaching vulnerable groups in CRVS through Data Collection Team formation at the district/city level. 


\section{References}

Bennouna, C., Feldman, B., Usman, R., Adiputra, R., Kusumaningrum, S., \& Stark, L. (2016). Using the Three Delays Model to Examine Civil Registration Barriers in Indonesia. PLoS ONE, 11(12), 1-15. https://doi.org/10.1371/journal.pone.0168405

Peraturan Menteri Dalam Negeri Nomor 19 tahun 2018 tentang Peningkatan Kualitas Layanan Administrasi Kependudukan, (2018).

KOMPAK, \& PUSKAPA. (2020). Menyambung Rantai Inklusi: Memahami Kerentanan dalam Sistem Administrasi Kependudukan di Indonesia.

Pusat Kajian dan Advokasi Perlindungan dan Kualitas Hidup Anak (PUSKAPA). (2020). Studi Kerentanan Administrasi Kependudukan.

Rijanta, R., Sartohadi, J., Baiquni, M., \& Hizbaron, D. (2019). Urban Vulnerability in Bantul District, Indonesia - Towards Safer and Sustainable Development. 726. https://doi.org/10.3390/wsf-00726

Undang-Undang Nomor 24 tahun 2013 tentang Administrasi Kependudukan, 232 (2013).

Undang-Undang Nomor 16 tahun 2019 tentang Perubahan atas Undang-Undang Nomor 1 tahun 1974 tentang Perkawinan., 186 (2019).

Keputusan Presiden Nomor 12 tahun 2020 tentang Penetapan Bencana Non-Alam Penyebaran Coronavirus Diseases 2019 (COVID-19) sebagai Bencana Nasional., (2020).

Sugiyono. (2018). Metode Penelitian Kuantitatif, Kualitatif dan REDD.

Suthar, A. B., Khalifa, A., Yin, S., Wenz, K., Fat, D. M., Mills, S. L., Nichols, E., AbouZahr, C., \& Mrkic, S. (2019). Evaluation of Approaches to Strengthen Civil Registration and Vital Statistics Systems: A Systematic Review and Synthesis of Policies in 25 $\begin{array}{llll}\text { Countries. } & \text { PLoS } & \text { Medicine, } & 16(9),\end{array}$ https://doi.org/10.1371/journal.pmed.1002929

Widarti Gularsih Sukino, Muhammad Ahsan Samad, Nasir Mangngasing, \& Abdul Rivai. (2019). Disaster Mitigation Management of Palu City. Journal of Public Administration and Government, 1(2), 1-8. https://doi.org/10.22487/jpag.v1i2.26 